Article

\title{
Catalytic Performances of Au-Pt Nanoparticles on Phosphorous Functionalized Carbon Nanofibers towards HMF Oxidation
}

\author{
Sebastiano Campisi ${ }^{1, *(\mathbb{D})}$, Sofia Capelli ${ }^{1}$, Davide Motta ${ }^{2}$, Felipe J Sanchez Trujillo ${ }^{2}$, \\ Thomas E. Davies ${ }^{2}$, Laura Prati ${ }^{1}$ (D), Nikolaos Dimitratos ${ }^{2}$ and Alberto Villa ${ }^{1, *}$ (iD \\ 1 Dipartimento di Chimica, Università degli Studi di Milano, via Golgi 19, 20133 Milano, Italy; \\ sofia.capelli@unimi.it (S.C.); laura.prati@unimi.it (L.P.) \\ 2 Cardiff Catalysis Institute, School of Chemistry, Cardiff University, Main Building, Park Place, \\ Cardiff CF10 3AT, UK; MottaD@cardiff.ac.uk (D.M.); SanchezF@cardiff.ac.uk (F.J.S.T.); \\ Daviests@cf.ac.uk (T.E.D.); DimitratosN@cardiff.ac.uk (N.D.) \\ * Correspondence: Sebastiano.Campisi@unimi.it (S.C.); Alberto.Villa@unimi.it (A.V.); \\ Tel.: +39-02-5031-4056 (S.C.); +39-02-50314361 (A.V.)
}

Received: 30 July 2018; Accepted: 17 August 2018; Published: 28 August 2018

\begin{abstract}
Herein, we reported the utilization of pre-formed $\mathrm{Au}-\mathrm{Pt}$ nanoparticles deposited on phosphorus functionalized carbons as effective catalysts for the oxidation of 5-hydroxymethylfurfural (HMF) to furandicarboxylic acid (FDCA). Au-Pt nanoparticles have been prepared by a two-step methodology using polyvinyl alcohol (PVA) as protective agent and a combination of $\mathrm{NaBH}_{4}$ and $\mathrm{H}_{2}$ as reducing agents. Three carbon nanofibers (CNFs) with different graphitization degrees have been functionalized through treatment with an $\mathrm{H}_{3} \mathrm{PO}_{4}-\mathrm{HNO}_{3}$ mixture at $150{ }^{\circ} \mathrm{C}$, in order to incorporate $\mathrm{P}$ groups on carbon surface. Surface and structural properties of the synthesized functionalized materials have been investigated by transmission electron microscopy (TEM), X-ray photoelectron spectroscopy (XPS), and Raman spectroscopy. The structural and surface properties of carbon nanofibers determine the amount of P-functionalities, which is a key parameter affecting the catalytic performances of $\mathrm{Au}-\mathrm{Pt}$. Indeed, the highest activity and stability has been achieved for $\mathrm{Au}-\mathrm{Pt}$ deposited on the sample, which showed the largest amount of P-groups on the surface.
\end{abstract}

Keywords: carbon materials; nanofibers; functionalization; heteroatoms; HMF oxidation; preformed colloidal Au-Pt nanoparticles

\section{Introduction}

Carbon materials have attracted a lot of attention in heterogeneous catalysis because of their low cost and good chemical and mechanical stability [1-4]. Activated carbon (AC), carbon nanotubes (CNTs), carbon nanofibers (CNFs), carbon nanocoils (CNCs), ordered mesoporous carbons (OMCs), and graphene have been used as supports for metal nanoparticles (i.e., $\mathrm{Au}, \mathrm{Pd}, \mathrm{Pt}, \mathrm{Ru}$ ) [5-7]. The utilization of carbon materials as catalyst supports for metal nanoparticles requires precise control over the surface chemistry in particular. This factor can strongly influence the metal active phase dispersion and electronic properties, which influence the overall catalytic performance [1,5]. A common strategy is the functionalization of the carbon surface with the incorporation of heteroatoms (commonly boron, nitrogen, oxygen, and phosphorus) [8-10]. Several studies have shown that the introduction of oxygen and nitrogen groups can modify the acid/base properties of carbon materials, but also improve the metal dispersion, increase the stability, and modify the electronic properties of the metal nanoparticles [11-17]. Beside $\mathrm{O}$ and $\mathrm{N}$-doped carbon, recently, the effect of the introduction of P-groups on carbon surface has been an object of study in electrocatalysis [18-24], acetylene 
hydrochlorination [25], and liquid phase hydrogenation and oxidation [26-28]. The beneficial effect of the functionalization of activated carbon with P groups on the activity and stability of Pd nanoparticles in the hydrogenation of nitroarenes has been reported [26]. The authors demonstrated that this result has been attributed to the capability of $\mathrm{P}$ to modify the electronic properties of $\mathrm{Pd}$ as a result of the transfer of electrons from $\mathrm{C}$ atoms to $\mathrm{P}$ atoms, favoring the formation of stable electron-rich $\mathrm{Pd}-\mathrm{P}$ species [26]. Guo et al., reported the high efficiency of carbon supported Pd-P alloy (Pd-P/PCF) for the benzyl alcohol oxidation [27]. They demonstrated that embedded $\mathrm{P}$ atoms influence the $3 \mathrm{~d}$ electron density of $\mathrm{Pd}$ and may weaken the binding of alcohol intermediates, thus promoting the catalytic performance of Pd-P/PCF. Pd deposited on nitrogen and phosphorus-codoped graphene sheets showed better activity than Pd on unfunctionalized carbon in the oxidation of 5-hydroxymethylfurfural (HMF) to furandicarboxylic acid (FDCA) [28]. The authors showed that the functionalization of graphene with $\mathrm{N}$ - and P-groups increases the fraction of surface $\mathrm{Pd}^{2+}$ species, which plays a determining role in reducing the activation energies of both HMF conversion and FDCA formation.

FDCA is an important high value product as it has been considered a potential replacement source of terephthalic acid, the monomer presently used for the production of polyethylene terephthalate (PET) as replacement of the oil-derived PET $[29,30]$. FDCA can be obtained by oxidation of HMF, which derived from the dehydration of fructose [31-33]. The synthesis of FDCA from HMF has been reported using molecular oxygen as oxidant in the presence of $\mathrm{Au}, \mathrm{Pt}, \mathrm{Pd}$, or $\mathrm{Ru}$ based heterogeneous catalysts, with water as the solvent and a base [34-42]. Moreover, the combination of two metals in particular, $\mathrm{Au}$ and $\mathrm{Pt}$, to form alloys has been reported to result in a catalytic system that is more effective than the corresponding monometallic counterparts [43,44].

We have recently used P-functionalized carbon nanofibers (P-CNFs) for the transformation of fructose into 5-hydroxymethylfurfural (HMF), showing that the incorporation of $\mathrm{P}$ groups on carbon nanofibers, with different graphitization degrees (pyrolytically striped carbon nanofibers (PS-CNFs), low-temperature heat treated carbon nanofibers (LHT-CNFs), and high-temperature heat treated carbon nanofibers (HHT-CNFs)), produces effective catalysts for this reaction [45].

In this work, we have utilized these materials as support for $\mathrm{Au}, \mathrm{Pt}$, and $\mathrm{Au}-\mathrm{Pt}$ nanoparticles as catalyst for the oxidation of HMF to FDCA. The aim is to investigate the role of $\mathrm{P}$ in enhancing the activity and the stability of the metal nanoparticles.

The effect of $\mathrm{P}$ amount has been evaluated in terms of activity, selectivity, and stability. Moreover, the effect of the reaction conditions (temperature, oxygen pressure, and $\mathrm{NaOH}$ amount) has been evaluated.

\section{Materials and Methods}

CNFs functionalization: commercial Pyrograph ${ }^{\circledR}-\mathrm{III}$ CNFs (code PR-24, average diameter of $100 \pm 30 \mathrm{~nm}$ and a specific surface area of $40-45 \mathrm{~m}^{2} / \mathrm{g}$ ) from Pyrograph Products, Inc. (Cedarville, OH, USA), an affiliate of Applied Science, Inc. (Grass Valley, CA, USA), were used as pristine carbon materials. In particular three samples thermally processed at different severity degrees were selected as carbonaceous substrates: vapor-grown carbon nanofibers treated at $700{ }^{\circ} \mathrm{C}$ (Pyrolytically Striped CNFs, hereafter shortened as PS-CNFs; average diameter of $100 \pm 30 \mathrm{~nm}$ and a specific surface area of $45 \mathrm{~m}^{2} / \mathrm{g}$ ), $1500{ }^{\circ} \mathrm{C}$ (Low-temperature Heat Treated CNFs, LHT-CNFs; average diameter of $100 \pm 30 \mathrm{~nm}$ and a specific surface area of $43 \mathrm{~m}^{2} / \mathrm{g}$ ), and $3000{ }^{\circ} \mathrm{C}$ (High-temperature Heat Treated CNFs, HHT-CNFs; average diameter of $100 \pm 30 \mathrm{~nm}$ and a specific surface area of $41 \mathrm{~m}^{2} / \mathrm{g}$ ). For the functionalization, $2 \mathrm{~g}$ of $\mathrm{CNF}$ sample were suspended in $250 \mathrm{~mL}$ of a $\mathrm{HNO}_{3}-\mathrm{H}_{3} \mathrm{PO}_{4}$ $1: 1 \mathrm{vol} / \mathrm{vol}$ mixture, stirred, and heated at $150{ }^{\circ} \mathrm{C}(2 \mathrm{~h})$. The functionalized carbon samples were then filtered, thoroughly washed with distilled water till neutrality, and finally dried at $100{ }^{\circ} \mathrm{C}$ overnight. Functionalized samples were labeled as P-PS-CNFs, P-LHT-CNFs, and P-HHT-CNFs.

\subsection{Catalyst Preparation}

$\mathrm{Au} / \mathrm{CNF}$ : Solid $\mathrm{NaAuCl}_{4} \cdot 2 \mathrm{H}_{2} \mathrm{O}$ (ca. $20 \mathrm{mg}$, corresponding to $\mathrm{Au}=0.051 \mathrm{mmol}=10 \mathrm{mg}$ ) and $0.5 \mathrm{~mL}$ of polyvinyl alcohol (PVA) $1 \mathrm{wt} \%$ solution (Au/PVA $=1 / 0.5 \mathrm{wt} / \mathrm{wt}$ ratio) were added to $100 \mathrm{~mL}$ of $\mathrm{H}_{2} \mathrm{O}$. 
After $5 \mathrm{~min}, 2 \mathrm{~mL}$ of a fresh solution of $\mathrm{NaBH}_{4}(0.1 \mathrm{M})\left(\mathrm{Au} / \mathrm{NaBH}_{4}=1 / 4 \mathrm{~mol} / \mathrm{mol}\right)$ was added to the yellow solution under stirring. Within a few minutes of sol generation, the colloid was immobilized by adding the support (ca. $1 \mathrm{~g}$ ) under vigorous stirring. The amount of support was calculated as having a total final metal loading of $1 \mathrm{wt} \%$. After $2 \mathrm{~h}$, the slurry was filtered, the catalyst was washed thoroughly with distilled water to remove PVA from the catalyst surface, and then dried at $80^{\circ} \mathrm{C}$ for $4 \mathrm{~h}$.

$\mathrm{Pt} / \mathrm{CNF}$ : Solid $\mathrm{K}_{2} \mathrm{PtCl}_{4}$ (ca. $20 \mathrm{mg}$, corresponding to $\mathrm{Pt}=0.051 \mathrm{mmol}=10 \mathrm{mg}$ ) and $0.5 \mathrm{~mL}$ of PVA ( $1 \mathrm{wt} \%$ ) solution ( $\mathrm{Pt} / \mathrm{PVA}=1 / 0.5 \mathrm{wt} / \mathrm{wt}$ ) were added to $100 \mathrm{~mL}$ of $\mathrm{H}_{2} \mathrm{O}$. After $5 \mathrm{~min}, \mathrm{H}_{2}$ was bubbled $(50 \mathrm{~mL} / \mathrm{min})$ under atmospheric pressure and room temperature for $2 \mathrm{~h}$. The colloid was immobilized by adding the support (ca. $1 \mathrm{~g}$ ) under vigorous stirring. The amount of support was calculated as having a total final metal loading of $1 \mathrm{wt} \%$. After $2 \mathrm{~h}$, the slurry was filtered, the catalyst was washed thoroughly with distilled water to remove PVA from the catalyst surface, and then dried at $80^{\circ} \mathrm{C}$ for $4 \mathrm{~h}$.

$\mathrm{Au}_{6} \mathrm{Pt}_{4} / \mathrm{CNFs}: \mathrm{NaAuCl}_{4} \cdot 2 \mathrm{H}_{2} \mathrm{O}$ (ca. $12 \mathrm{mg}$ corresponding to $\mathrm{Au}=0.031 \mathrm{mmol}=6 \mathrm{mg}$ ) was dissolved in $60 \mathrm{~mL}$ of $\mathrm{H}_{2} \mathrm{O}$, and $0.3 \mathrm{~mL}$ PVA $(1 \%$, wt \%) was added $(\mathrm{Au} / \mathrm{PVA}=1 / 0.5 \mathrm{wt} / \mathrm{wt})$. The yellow solution was stirred for $3 \mathrm{~min}$, after which $1.2 \mathrm{~mL}$ of a fresh solution of $0.1 \mathrm{M} \mathrm{NaBH}_{4}$ $\left(\mathrm{Au} / \mathrm{NaBH}_{4}=1 / 4 \mathrm{~mol} / \mathrm{mol}\right)$ was added under vigorous magnetic stirring. Within a few minutes of sol generation, the gold sol was immobilized by adding the support (ca. $1 \mathrm{~g}$ ) under vigorous stirring. The amount of support was calculated as having a gold loading of $0.60 \mathrm{wt} \%$. After $2 \mathrm{~h}$, the slurry was filtered and the catalyst washed thoroughly with distilled water (neutral mother liquors). The $\mathrm{Au}$ /support was dispersed in $40 \mathrm{~mL}$ of water, with $\mathrm{K}_{2} \mathrm{PtCl}_{4}$ (ca. $8 \mathrm{mg}$ corresponding to $\mathrm{Pt}=0.021 \mathrm{mmol}=4 \mathrm{mg}$ ) and $0.2 \mathrm{~mL}$ PVA solution $(\mathrm{Pt} / \mathrm{PVA}=1 / 0.5 \mathrm{wt} / \mathrm{wt})$ added. $\mathrm{H}_{2}$ was bubbled $(50 \mathrm{~mL} / \mathrm{min})$ under atmospheric pressure and room temperature for $2 \mathrm{~h}$. The slurry was filtered, the catalyst was washed thoroughly with distilled water to remove PVA from the catalyst surface, and then dried at $80^{\circ} \mathrm{C}$ for $4 \mathrm{~h}$. The total nominal metal loading was $1 \mathrm{wt} \%$.

\subsection{Catalytic Tests}

The reactions were performed in a stainless steel reactor equipped with a magnetic stirrer. HMF $0.15 \mathrm{M}$ and the catalyst (substrate $/$ total metal $=50 / 500 \mathrm{~mol} / \mathrm{mol}$ ) were mixed in distilled water (total volume $10 \mathrm{~mL}$ ), in presence of $\mathrm{NaOH}$ (1-4 equiv) or under base free conditions. The reactor was pressurized at $1-5 \mathrm{~atm}$ of oxygen and set to $30-80^{\circ} \mathrm{C}$. Once the temperature was reached, the gas supply was switched to oxygen and the monitoring of the reaction started. The reaction was initiated by stirring.

Samples were removed periodically and analyzed by high performance liquid chromatography (HPLC, Agilent Technologies, 1220 Infinity, Santa Clara, CA, USA) using a column $(\mathrm{L} \times$ i.d.: $300 \mathrm{~mm} \times 7.8 \mathrm{~mm}$, Alltech OA-10308, Fisher Scientific, Hampton, NH, USA) with ultraviolet (UV) and refractive index (RI) detection to analyze the mixture of the samples. Aqueous $\mathrm{H}_{3} \mathrm{PO}_{4}$ solution $(0.1 \mathrm{wt}$ $\%$ ) was used as the eluent. Products were identified and quantified by comparison with the original standard samples. The selectivity to products was calculated based on the number of carbon atoms. The difference in concentration from the carbon mass balance was attributed to unknown products detected on HPLC chromatograms. The catalyst was recycled in the subsequent run after filtration without any further treatment. The recovery of the catalyst was always $>98 \%$.

\subsection{Characterization of Catalysts}

Raman spectroscopy was performed with a Renishaw inVia Raman microscope (Wotton-underEdge, Gloucestershire, UK). Bare supports and fresh catalysts were analyzed. Typically, a sample of approximately $0.01 \mathrm{~g}$ Awas placed on a metal slide inside the spectrometer. The powder was analyzed under an IR class laser $(514 \mathrm{~nm}$ ) with a laser intensity of $50 \%$. The sample was scanned at an attenuation time of $22 \mathrm{~s}$ and 10 scans were carried out to give a spectrum.

Particle size distributions and mean particle size were obtained by means of TEM using a JEOL JEM 2100 TEM operating at $200 \mathrm{kV}$ (Peabody, MA, USA). Samples for examination were prepared by dispersing the catalyst in high purity ethanol. A drop of the suspension was allowed to evaporate on a holey carbon film supported by a 300-mesh copper TEM grid. Samples were subjected to bright 
field diffraction contrast imaging experiments. Mean particle sizes and particle size distributions were determined by measuring the size of over 200 particles from different selected areas.

The actual metal loading was verified by atomic absorption spectroscopy (AAS) analysis, on a Perkin Elmer 3100 instrument (Waltham, MA, USA). After filtration and washing of as-prepared catalysts, residual metal content in the filtrate was evaluated by the method of standard additions.

X-ray photoelectron spectroscopy (XPS) was performed on a Thermo Scientific K-alpha spectrometer (Waltham, MA, USA). Samples were analyzed using a monochromatic Al X-ray source operating at $72 \mathrm{~W}(6 \mathrm{~mA} \times 12 \mathrm{kV})$, with the signal averaged over an oval-shaped area of approximately $600 \times 400$ microns. Data was recorded at pass energies of $150 \mathrm{eV}$ for survey scans and $40 \mathrm{eV}$ for high resolution scan with a $1 \mathrm{eV}$ and $0.1 \mathrm{eV}$ step size, respectively. Charge neutralization of the sample was achieved using a combination of both low energy electrons and argon ions (less than $1 \mathrm{eV}$ ), which gave a binding energy of $284.8 \mathrm{eV}$ for the $\mathrm{sp}^{3}$ component of $\mathrm{C} 1 \mathrm{~s}$.

All data were analyzed using CasaXPS (v2.3.17 PR1.1, Teignmouth, Devon, UK) using Scofield sensitivity factors and an energy exponent of -0.6. The regions of $\mathrm{C} 1 \mathrm{~s}$ and $\mathrm{Au} 4 \mathrm{f}$ and $\mathrm{Pt} 4 \mathrm{f}$ have been fitted using a Shirley type background.

\section{Results}

Carbon nanofibers (CNFs) treated at $700{ }^{\circ} \mathrm{C}$ (pyrolytically striped, PS-CNFs), $1500{ }^{\circ} \mathrm{C}(\mathrm{LHT}-\mathrm{CNFs})$, and $3000{ }^{\circ} \mathrm{C}$ (HHT-CNFs) were used as supports for $\mathrm{Au}-\mathrm{Pt}$ nanoparticles. The heat treatment modifies the graphitization degree of CNFs, with HHT-CNFs being the more graphitized according to Raman spectra analysis (Table 1). A portion of these materials have been functionalized, introducing phosphorus-containing groups on the surface. We have previously shown that the surface chemistry of CNFs, in particular the graphitization degree, could influence the amount of introduced P [45]. XPS analysis has shown the presence of $1.19 \%$ of $\mathrm{P}$ on the surface of P-HHT-CNFs, whereas a lower amount has been observed for P-PS-CNFs and P-LHT-CNFs ( $0.23 \%$ and $0.24 \%$, respectively, Table 2$)$. Raman analysis has shown that the functionalization has a different impact on the resulting graphitization degree on the three different CNFs. In the case of PS-CNFs, the acid functionalization increased the graphitization $\left(I_{D} / I_{G}\right.$ of 0.69 and 0.37 for PS-CNFs and P-PS-CNFs, respectively, Table 1$)$, probably removing the amorphous carbon present on PS-CNFs surface [46]. On the contrary, the functionalization negatively impacts on the graphitization of the LHT-CNFs $\left(I_{D} / I_{G}\right.$ of 0.93 and 1.18 for LHT-CNFs and P-LHT-CNFs, respectively, Table 1), whereas no significant modifications were observed for HHT-CNFs $\left(I_{D} / I_{G}\right.$ of 0.12 and 0.14 for HHT-CNFs and P-HHT-CNFs, respectively, Table 1$)$.

Table 1. Graphitization degree from Raman spectra. CNF—carbon nanofibers.

\begin{tabular}{ccc}
\hline \multirow{2}{*}{ Sample Name } & \multicolumn{2}{c}{ Graphitization Degree $\left(\boldsymbol{I}_{\boldsymbol{D}} / \mathbf{I}_{G}\right)^{\mathbf{1}}$} \\
\cline { 2 - 3 } & Pristine & $\mathbf{P}-\mathrm{CNFs}$ \\
\hline PS-CNFs & 0.69 & 0.37 \\
LHT-CNFs & 0.93 & 1.18 \\
HHT-CNFs & 0.12 & 0.14
\end{tabular}

1 The peak fitting analysis was performed by deconvolution with four Lorentzian curves (in the region $\left.1200-1750 \mathrm{~cm}^{-1}\right)$, accounting for $\mathrm{D}, \mathrm{D}^{\prime}, \mathrm{G}$, and $\mathrm{D}^{\prime \prime}$ peaks [47].

Table 2. Surface atomic composition from X-ray photoelectron spectroscopy (XPS) analysis.

\begin{tabular}{cc}
\hline Sample & $\begin{array}{c}\text { Atomic Ratio \% } \\
\text { C:O:P }\end{array}$ \\
\hline P-PS-CNFs & $87.12: 12.65: 0.23$ \\
P-LHT-CNFs & $96.06: 3.70: 0.24$ \\
P-HHT-CNFs & $90.89: 7.92: 1.19$ \\
\hline
\end{tabular}


$\mathrm{Au}-\mathrm{Pt}$ catalysts have been prepared using a two-step procedure developed by our group that ensures the formation of homogeneously alloyed Au-Pt nanoparticles [48]. Gold was first deposited on the support as PVA-protected nanoparticles. In the second step, Pt precursor solution was added to the solid $\mathrm{Au}$ /support material and slowly reduced by $\mathrm{H}_{2}$. Monometallic $\mathrm{Au}$ and $\mathrm{Pt}$ have been prepared for comparison. The introduction of $\mathrm{Au}-\mathrm{Pt}$ nanoparticles had an unexpected effect on the graphitization of the materials (Table 1). Indeed, the $I_{D} / I_{G}$ ratio did not change for P-PS-CNFs, whereas the graphitization decreased for P-LHT-CNFs and increased for P-HHT-CNFs (Table 1). The reason for this trend remains unclear. Transmission electron microscopy (TEM) has been utilized to determine the morphology of Au-Pt nanoparticles. Similar mean metal particle size in the range of 4-5 $\mathrm{nm}$ has been observed for the catalysts, (Table S1, Figure 1). In all the sample, metal nanoparticles were homogeneously dispersed on the external CNF surface.
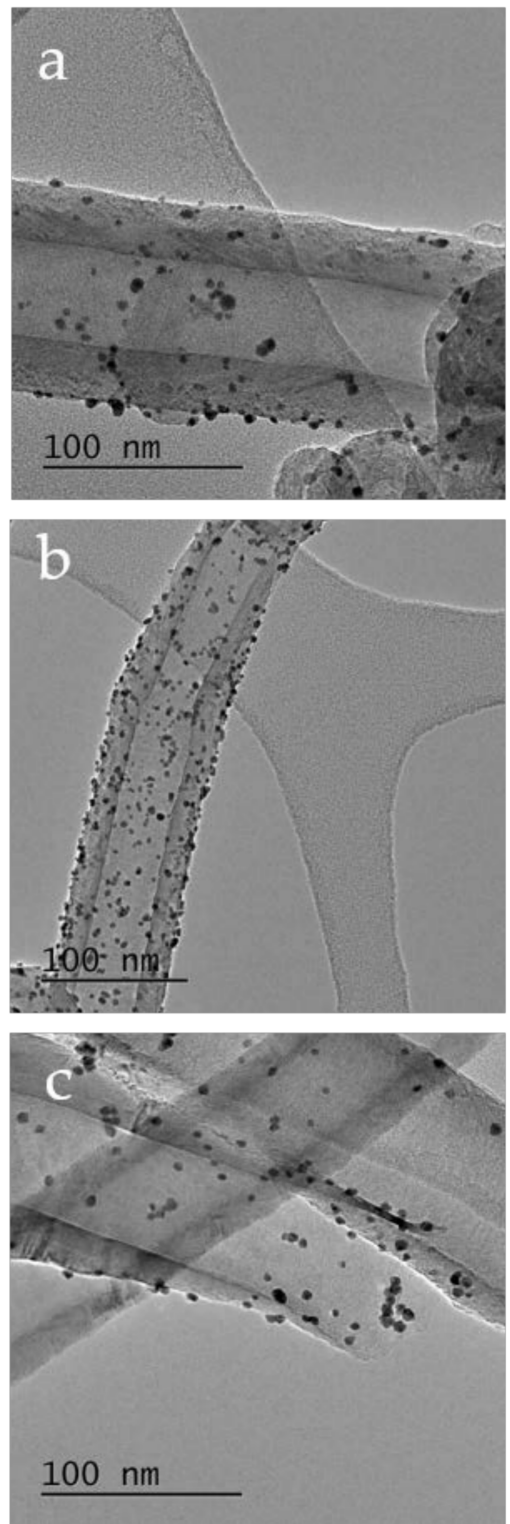
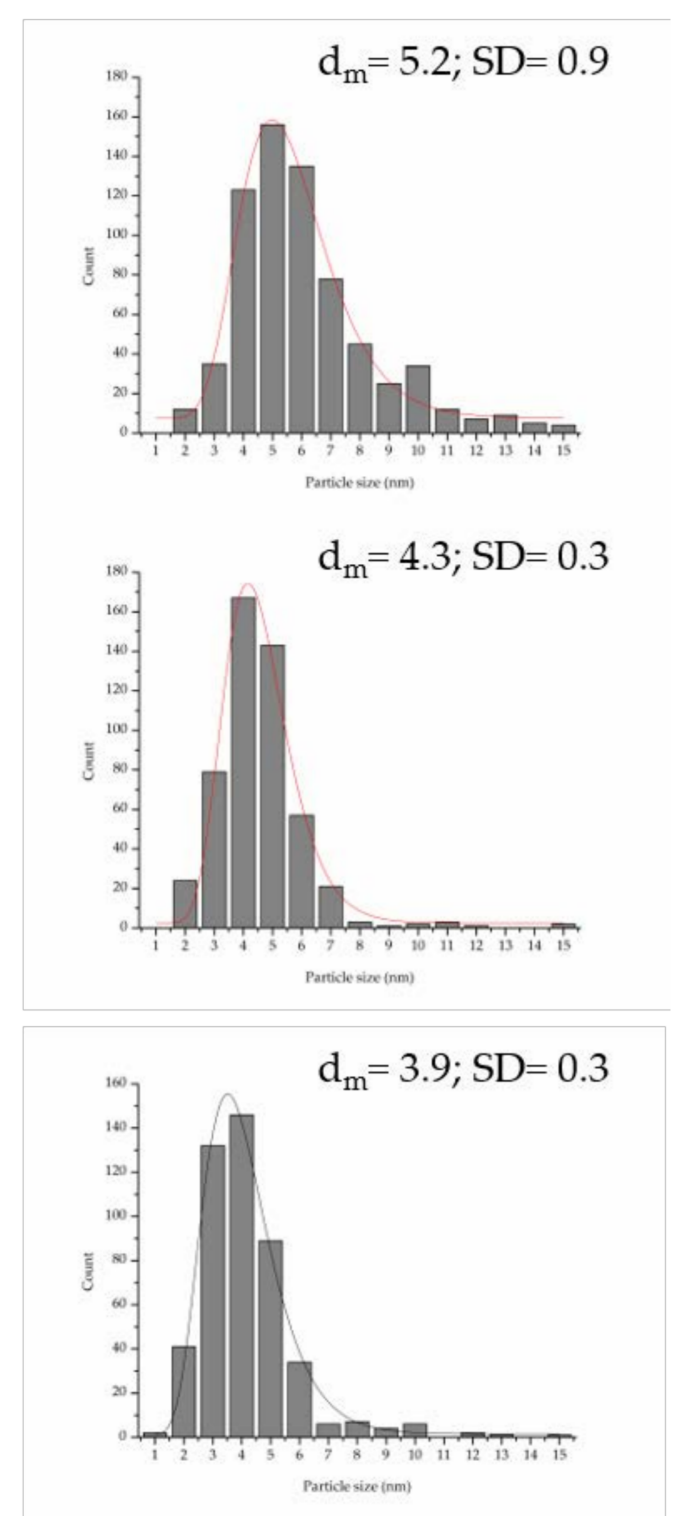

Figure 1. Low resolution transmission electron microscopy (TEM) micrographs and histograms of particle size distribution (right side) of Au-Pt/P-PS-carbon nanofiber (CNF) (a); Au-Pt/P-LHT-CNF (b); and Au-Pt/P-HHT-CNF (c) catalysts. 
Scanning transmission electron microscopy (STEM) images showed a non-optimal dispersion of metal nanoparticles with the presence of few agglomerates regardless the support used (Figure 2).
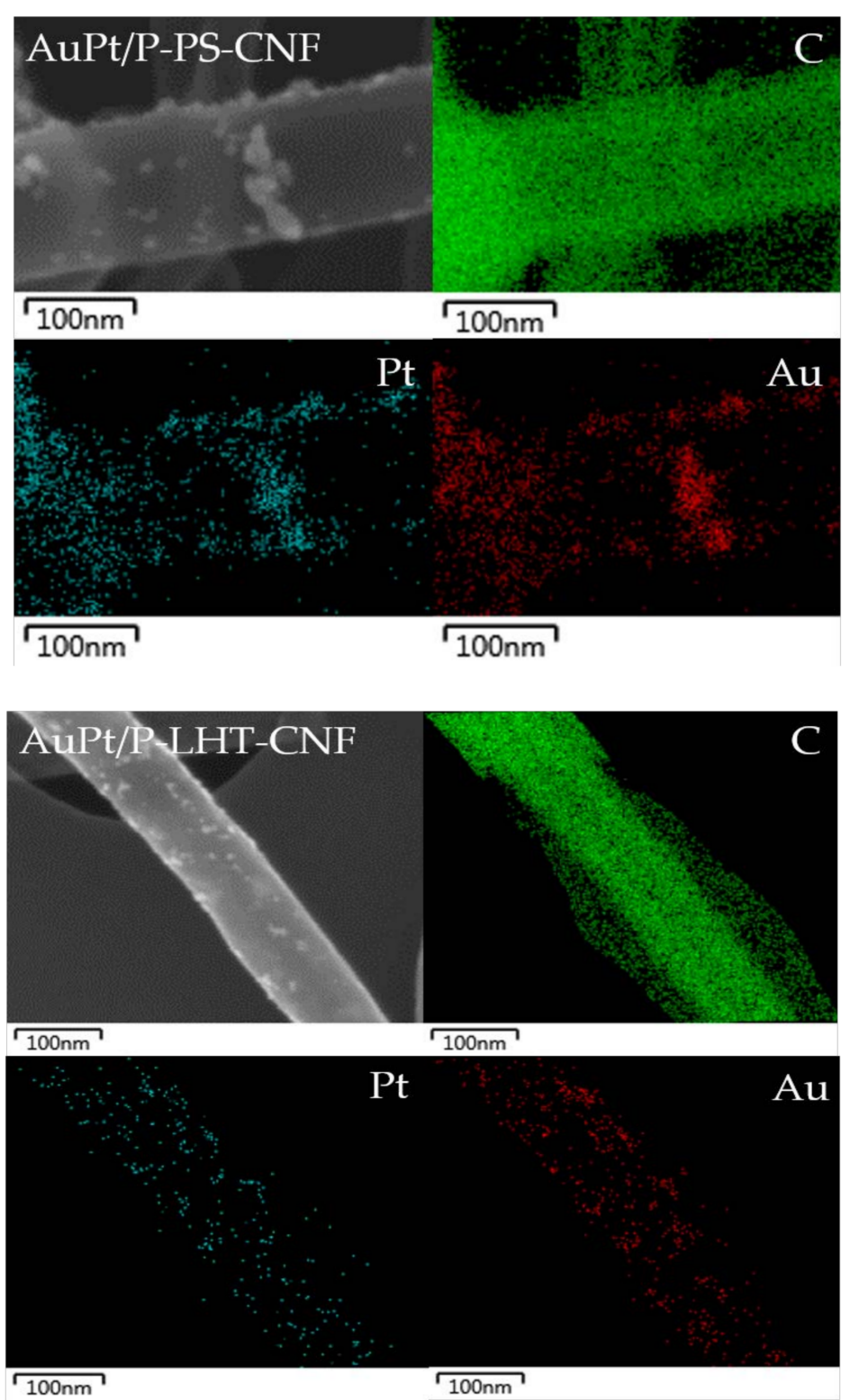

Figure 2. Cont. 


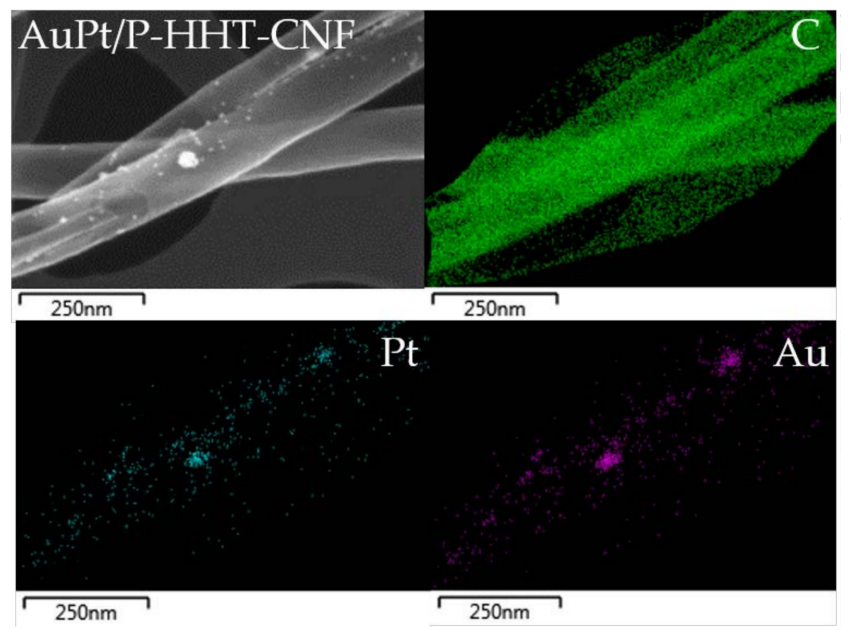

Figure 2. Scanning transmission electron microscopy (STEM) and energy dispersive X-ray (EDX) mapping images of Au-Pt/P-PS-CNF, Au-Pt/P-LHT-CNF, and Au-Pt/P-HHT-CNF catalysts.

The catalytic performance of the prepared $\mathrm{Au}-\mathrm{Pt}$ nanoparticles supported on functionalized carbon nanofibers has been evaluated in the oxidation of $\mathrm{HMF}$ using the reactions conditions reported in our previous studies (HMF 0.15 M, Alcohol $/$ metal: $200 \mathrm{~mol} / \mathrm{mol}, \mathrm{T}=60{ }^{\circ} \mathrm{C}, \mathrm{pO}_{2}=3 \mathrm{~atm}, 2 \mathrm{equiv}$. $\mathrm{NaOH}$ ) (Table 3) [44]. The influence of catalyst amount and stirring rate has been investigated to be sure to work under kinetic regime (Figures S1 and S2). The main products detected were 5-hydroxymethyl-2-furancarboxylic acid (HFCA), deriving from the oxidation of the carbonyl group of HMF, and 2,5-furandicarboxylic acid (FDCA), the desired product, derived from the oxidation of both carbonyl and alcoholic group (Scheme 1).

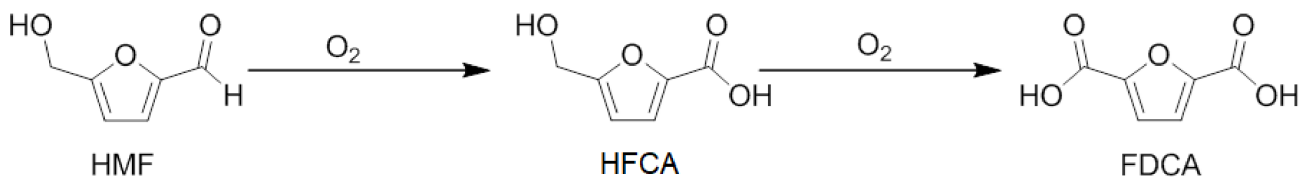

Scheme 1. Main products from 5-hydroxymethylfurfural (HMF) oxidation.

Table 3 reports the activity, the conversion after $2 \mathrm{~h}$, and the selectivity at iso-conversion (80\%). The activity has been calculated as mol of converted HMF per mol of metal per hour and was calculated after 15 min of reaction. The comparison between Au-Pt and the corresponding monometallic Au and Pt was initially considered using PS-CNF as a reference support. The beneficial synergistic effect of the bimetallic systems was envisaged with an activity of $\mathrm{Au}-\mathrm{Pt}\left(136 \mathrm{~h}^{-1}\right)$ higher than $\mathrm{Au}\left(92 \mathrm{~h}^{-1}\right)$ and $\mathrm{Pt}$ $\left(58 \mathrm{~h}^{-1}\right)$. Considering the bimetallic systems on pristine CNFs, it can be observed that Au-Pt/PS-CNF and $\mathrm{Au}-\mathrm{Pt}$ /LHT-CNF showed almost the same activity $\left(136 \mathrm{~h}^{-1}\right.$ and $140 \mathrm{~h}^{-1}$, respectively) and selectivity as FDCA (51\% and 54\% at 90\% conversion, respectively). On the contrary, Au-Pt/HHT-CNF showed a better performance with an activity of $185 \mathrm{~h}^{-1}$ and a selectivity to FDCA of $68 \%$. These results cannot be explained in terms of particle size being similar for the three catalysts (Table S1), but probably to the higher graphitization degree of the functionalized CNF support. Similar findings have been reported for glycerol oxidation under similar reaction conditions, where the higher activity has been correlated with a lower amount of structural defects, leading to Au particles strongly anchored to the orderly exposed graphite edges $[49,50]$. The introduction of a small amount $(\sim 0.2 \%)$ of phosphorous in P-PS-CNF and P-LHT-CNF slightly increased the activity of Au-Pt catalysts compared with undoped $\mathrm{Au} / \mathrm{PS}-\mathrm{CNF}$ and Au-Pt/LHT-CNF (Table 3). The higher P content in P-HHT-CNF (1.19\%) has a higher impact on the activity of $\mathrm{Au}-\mathrm{Pt}\left(368 \mathrm{~h}^{-1}\right.$ and $185 \mathrm{~h}^{-1}$, for Au-Pt/P-HHT-CNF and Au-Pt/HHT-CNF, respectively) with almost full conversion and $96 \%$ of selectivity to FDCA after only $1 \mathrm{~h}$. 
Table 3. Activity of Au-Pt catalysts in 5-hydroxymethylfurfural (HMF) oxidation a

\begin{tabular}{|c|c|c|c|c|c|}
\hline \multirow{2}{*}{ Catalyst } & \multirow{2}{*}{$\begin{array}{l}\text { Activity } \\
\left(h^{-1}\right)^{b}\end{array}$} & \multirow{2}{*}{$\begin{array}{c}\text { Conversion } \% \\
\text { After } 2 \mathrm{~h}\end{array}$} & \multicolumn{3}{|c|}{ Selectivity $^{\mathrm{d}}$} \\
\hline & & & HFCA & FDCA & Others \\
\hline $\mathrm{Au} / \mathrm{PS}-\mathrm{CNF}$ & 92 & 54 & $53^{e}$ & $43^{e}$ & $4^{\mathrm{e}}$ \\
\hline $\mathrm{Pt} / \mathrm{PS}-\mathrm{CNF}$ & 58 & 43 & $73^{\mathrm{e}}$ & $22^{\mathrm{e}}$ & $5^{e}$ \\
\hline $\mathrm{Au}-\mathrm{Pt} / \mathrm{PS}-\mathrm{CNF}$ & 136 & 83 & 47 & 51 & 2 \\
\hline $\mathrm{Au}-\mathrm{Pt} / \mathrm{LHT}-\mathrm{CNF}$ & 140 & 86 & 45 & 54 & 1 \\
\hline $\mathrm{Au}-\mathrm{Pt} / \mathrm{HHT}-\mathrm{CNF}$ & 185 & 88 & 30 & 68 & 2 \\
\hline $\mathrm{Au}-\mathrm{Pt} / \mathrm{P}-\mathrm{PS}-\mathrm{CNF}$ & 144 & 90 & 41 & 56 & 3 \\
\hline $\mathrm{Au}-\mathrm{Pt} / \mathrm{P}-\mathrm{LHT}-\mathrm{CNF}$ & 171 & 92 & 36 & 61 & 3 \\
\hline $\mathrm{Au}-\mathrm{Pt} / \mathrm{P}-\mathrm{HHT}-\mathrm{CNF}$ & 368 & $98^{c}$ & 2 & 96 & 2 \\
\hline
\end{tabular}

${ }^{\text {a }}$ Reaction conditions: HMF $0.15 \mathrm{M}$, alcohol/metal molar ratio: $200, \mathrm{~T}=60{ }^{\circ} \mathrm{C}, \mathrm{pO}_{2}=3 \mathrm{~atm}, 2$ eq. $\mathrm{NaOH}$;

${ }^{b}$ mol of HMF converted per hour per mol of metal, calculated after 15 min reaction; ${ }^{c}$ conversion after $1 \mathrm{~h}$; ${ }^{\mathrm{d}}$ selectivity at $90 \%$ of conversion; e selectivity at $40 \%$ of conversion. FDCA-2,5-furandicarboxylic acid; HFCA-5-hydroxymethyl-2-furancarboxylic acid.

The beneficial effect of $\mathrm{P}$ cannot be attributed to possible changes in Au-Pt aggregation state, as the nanoparticle size is similar to $\mathrm{Au}-\mathrm{Pt} / \mathrm{HHT}-\mathrm{CNF}$ (4.5 and $3.9 \mathrm{~nm}$ for $\mathrm{Au}-\mathrm{Pt} / \mathrm{HHT}-\mathrm{CNF}$ and $\mathrm{Au}-\mathrm{Pt} / \mathrm{P}-\mathrm{HHT}-\mathrm{CNF}$, respectively), but rather to the capability of $\mathrm{P}$ to modify the electronic properties of the metal active sites, as already envisaged in previous studies for Pd [26-28].

To verify this hypothesis, XPS analysis was performed to unravel eventual electronic modifications induced on metal NPs by P functionalities of doped CNF surface (Table 4). XPS analysis confirmed the presence of $P$ on the catalyst surface. Single $P$ peaks with BE in the range of $133.5-134.0 \mathrm{eV}$ revealed that $\mathrm{P}$ is prevalently present as phosphate groups in all the catalysts, as reported in our previous work [45]. Compared with the reference XPS data from bulk metal materials $\left(84.0 \mathrm{eV}\right.$ and $71.0 \mathrm{eV}$ for $\mathrm{Au} 4 \mathrm{f}_{7 / 2}$ and $\mathrm{Pt} 4 \mathrm{f}_{7 / 2}$, respectively), slight shifts toward higher binding energy were observed in both $\mathrm{Au}$ and $\mathrm{Pt}$ XPS peaks. The relatively more pronounced shift in $\mathrm{Au}$ peak was revealed for the $\mathrm{Au}-\mathrm{Pt} / \mathrm{P}-\mathrm{HHT}-\mathrm{CNF}$ sample $(84.12 \mathrm{eV})$. Concerning the Pt XPS signals, the peaks centered at 71.28 and ca. $72.5 \mathrm{eV}$ can be assigned to the $\mathrm{Pt} 4 \mathrm{f}_{7 / 2}$ of the $\mathrm{Pt}$ metallic state $\left(\mathrm{Pt}^{0}\right)$ and to oxidized $\mathrm{Pt}$ species $\left(\mathrm{Pt}^{2+}\right)$, respectively. It is noted that the position of $\mathrm{Pt}^{0}$ signal is not affected by the nature of the support, being exactly the same (71.28 eV) for Au-Pt/P-PS-CNF, Au-Pt/P-LHT-CNF, and Au-Pt/P-HHT-CNF. Differently, the binding energy for $\mathrm{Pt}^{2+}$ signal increases according to the following order: $\mathrm{Au}-\mathrm{Pt} / \mathrm{P}-\mathrm{HHT}-\mathrm{CNF}$ $(72.40 \mathrm{eV})<\mathrm{Au}-\mathrm{Pt} / \mathrm{P}-\mathrm{LHT}-\mathrm{CNF}(72.49 \mathrm{eV})<\mathrm{Au}-\mathrm{Pt} / \mathrm{P}-\mathrm{PS}-\mathrm{CNF}(72.60 \mathrm{eV})$. Quantitative analysis of the $\mathrm{Pt}^{0} / \mathrm{Pt}^{2+}$ atomic surface ratio showed that in all catalysts, the $\mathrm{Pt}$ metallic state was predominant and this is more evident in $\mathrm{Au}-\mathrm{Pt} / \mathrm{P}-\mathrm{HHT}-\mathrm{CNF}$. In particular, the $\mathrm{Pt}^{0} / \mathrm{Pt}^{2+}$ atomic surface ratio increases in the order Au-Pt/P-PS-CNF (4.7) < Au-Pt/P-LHT-CNF (6.4) < Au-Pt/P-HHT-CNF (7.6), reflecting the increase of $P$ content (Table 2). Consequently, it seems that a support P-rich surface induces a decrease in the electron density of $\mathrm{Au}$ atoms and the stabilization of $\mathrm{Pt}^{0}$ species, which are less prone to be oxidized. Both these pieces of evidence could explain the observed trends in catalytic data reported in Table 3, as discussed below (Section 4).

Table 4. Summary of the core-level XPS spectra of the catalyst.

\begin{tabular}{cccccc}
\hline \multirow{2}{*}{ Catalyst } & \multicolumn{3}{c}{$\mathbf{P t} \mathbf{4 f}_{7 / 2}$} & $\mathbf{A u} \mathbf{4 f}_{7 / 2}$ & $\mathbf{P} \mathbf{~ s}$ \\
\cline { 2 - 6 } & $\mathbf{P t}^{\mathbf{0}} \mathbf{B E} \mathbf{( e V )}$ & $\mathbf{P t}^{2+} \mathbf{B E}(\mathbf{e V})$ & $\mathbf{P t}^{0} / \mathbf{P t}^{\mathbf{2 +}} \mathbf{R a t i o}$ & $\mathbf{B E}(\mathbf{e V})$ & $\begin{array}{c}\mathbf{C}-\mathbf{O}-\mathbf{P O}_{3} \mathbf{C}-\mathbf{P} \\
\mathbf{B E}(\mathbf{e V})\end{array}$ \\
\hline $\mathrm{Au}-\mathrm{Pt} / \mathrm{P}-\mathrm{PS}-\mathrm{CNF}$ & 71.28 & 72.60 & 4.7 & 84.07 & 133.38 \\
$\mathrm{Au}-\mathrm{Pt} / \mathrm{P}-\mathrm{LHT}-\mathrm{CNF}$ & 71.28 & 72.49 & 6.4 & 84.06 & 133.68 \\
$\mathrm{Au}-\mathrm{Pt} / \mathrm{P}-\mathrm{HHT}-\mathrm{CNF}$ & 71.28 & 72.40 & 7.6 & 84.12 & 134.08 \\
\hline
\end{tabular}

To better understand the different catalytic behavior, in particular, the different selectivity to FDCA at iso-conversion of Au-Pt/P-PS-CNF (56\%), Au-Pt/P-LHT-CNF (61\%), and Au-Pt/P-HHT-CNF 
(96\%), the products distribution as a function of time of reaction has been analyzed. Figure 3 showed a different rate in the conversion of HFCA to FDCA using the three different catalysts. The conversion rate of HFCA to FDCA increased in the following order: Au-Pt/P-PS-CNF $<\mathrm{Au}-\mathrm{Pt} / \mathrm{P}-\mathrm{LHT}-\mathrm{CNF}<$ $\mathrm{Au}-\mathrm{Pt} / \mathrm{P}-\mathrm{HHT}-\mathrm{CNF}$. In other words, $\mathrm{Au}-\mathrm{Pt} / \mathrm{P}-\mathrm{PS}-\mathrm{CNF}$ and $\mathrm{Au}-\mathrm{Pt} / \mathrm{P}-\mathrm{LHT}-\mathrm{CNF}$ are able to easily oxidize the carbonyl group, resulting in the formation of HFCA but not in the oxidation of the alcoholic group, whereas $\mathrm{Au}-\mathrm{Pt} / \mathrm{P}-\mathrm{HHT}-\mathrm{CNF}$ is effective in the oxidation of both groups.

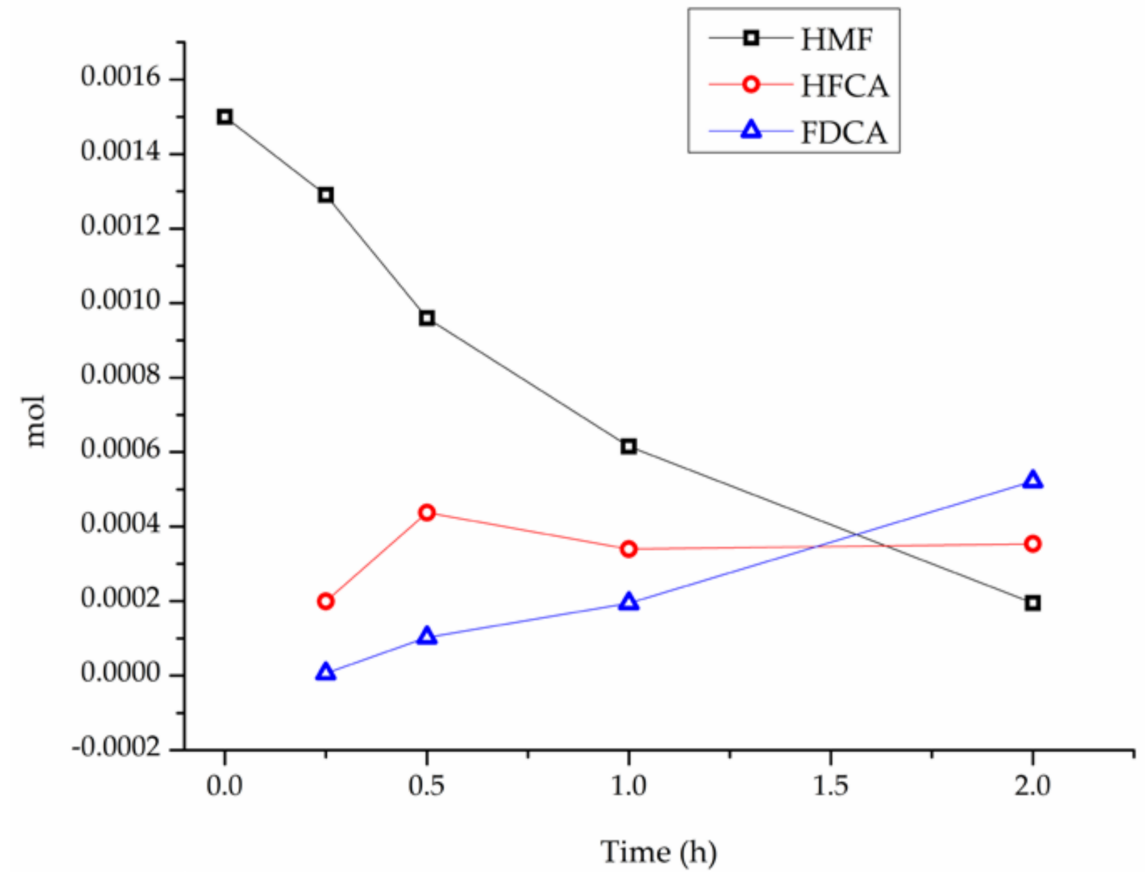

(a)

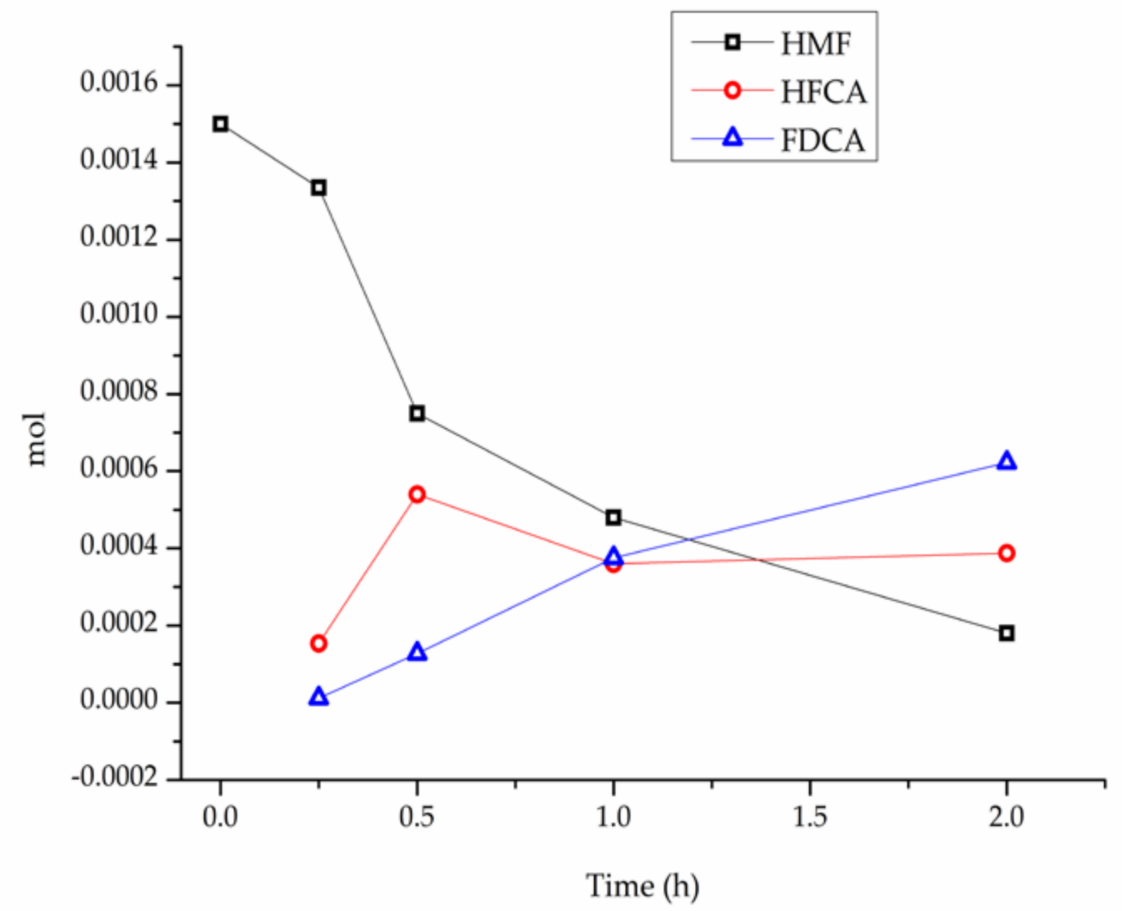

(b)

Figure 3. Cont. 


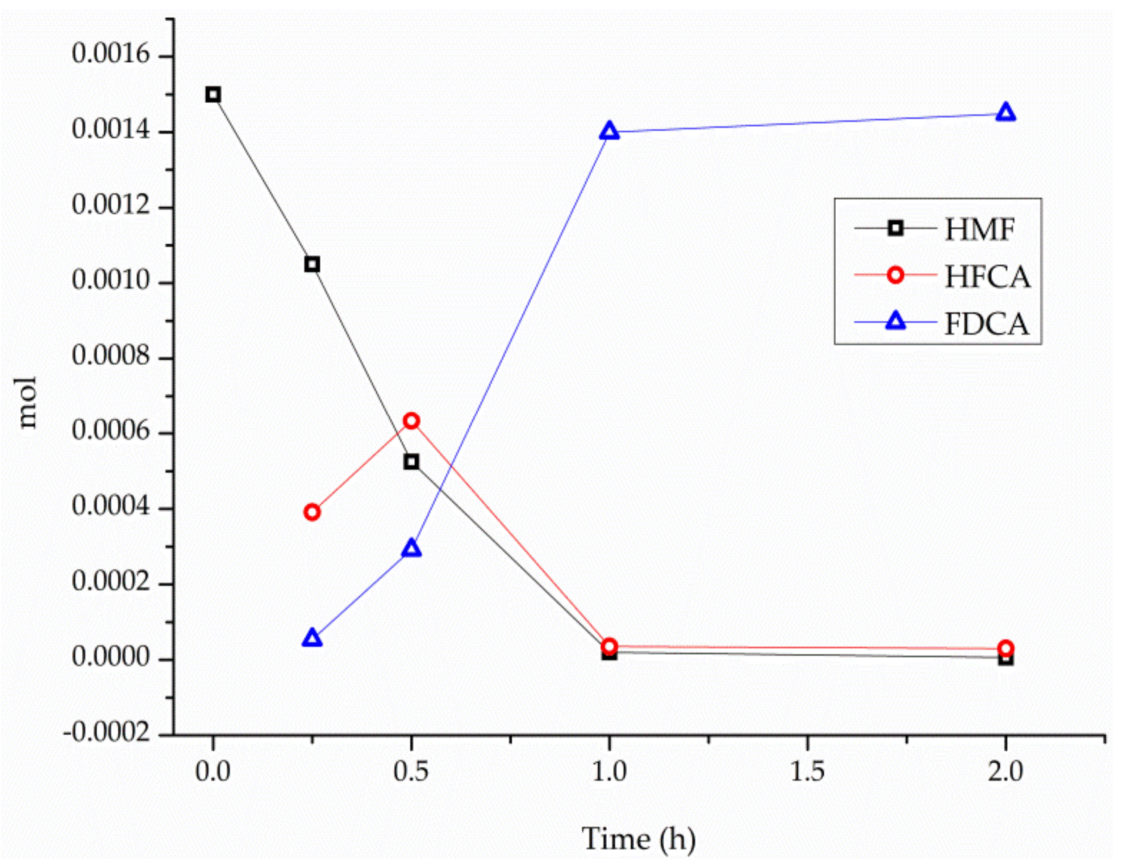

(c)

Figure 3. Product distribution for (a) Au-Pt/P-PS-CNF; (b) Au-Pt/P-LHT-CNF; and (c) Au-Pt/ P-HHT-CNF (HMF-5-hydroxymethylfurfural; FDCA-2,5-furandicarboxylic acid; HFCA-5hydroxymethyl-2-furancarboxylic acid).

The effect of reaction parameters, in particular, $\mathrm{NaOH}$ amount, temperature, and $\mathrm{O}_{2}$ pressure, have been investigated for the most active catalyst, Au-Pt/P-HHT-CNF.

Initially, the effect of the base amount has been considered. As reported in previous works [34-37], the presence and the amount of base is a key parameter in HMF oxidation to FDCA. In the absence of base, very low HMF conversion was observed; moreover, FDCA and other byproducts are insoluble in acidic media and tend to precipitate on the catalyst surface, thus contributing to fast catalyst deactivation. The addition of a base stabilizes FDCA in its anionic form and prevents the degradation of HMF. The reported optimal value for gold catalysts is four equivalents. When lower concentrations of base are used, a negligible amount of FDCA is produced, making the intermediate oxidation product (HFCA) the main product. On the other hand, when more than four equivalents of $\mathrm{NaOH}$ are used, no significant improvements in the catalytic performances have been observed. In our experiments, the $\mathrm{NaOH}$ amount varied from 0 to 4 equiv., keeping constant the temperature $\left(60^{\circ} \mathrm{C}\right)$ and the oxygen pressure ( $3 \mathrm{~atm}$ ) (Table 5). It should be noted that 2 equiv. corresponds to the stoichiometric amount needed to neutralize the two acid groups of FDCA. Increasing $\mathrm{NaOH}$ amount to 4 equiv., the activity increases, but the selectivity to FDCA decreased from 96 to 92 because of the formation of unknown products. When a lower amount than the stoichiometric one is used, the catalyst possesses lower activity, in particular, in the transformation of HFCA to FDCA, confirming previous evidence from the literature [34-37]. In particular, running the reaction in the absence of a base $(\mathrm{pH}=5)$, $\mathrm{Au}-\mathrm{Pt} / \mathrm{P}-\mathrm{HHT}-\mathrm{CNF}$ is still active, but only 15\% of conversion has been obtained after $1 \mathrm{~h}$. Moreover, almost no FDCA has been observed with the formation of $40 \%$ of unknown products, probably because of the decomposition of HFCA under acidic conditions. 
Table 5. Effect of $\mathrm{NaOH}$ amount using $\mathrm{Au}-\mathrm{Pt} / \mathrm{P}-\mathrm{HHT}-\mathrm{CNF}^{\mathrm{a}}$.

\begin{tabular}{cccccc}
\hline \multirow{2}{*}{ NaOH Equiv. } & \multirow{2}{*}{$\begin{array}{c}\text { Activity } \\
\mathbf{( h}^{-\mathbf{1}} \mathbf{)}\end{array}$} & $\begin{array}{c}\text { Conversion } \\
\text { After } \mathbf{1} \mathbf{~ h}\end{array}$ & & \multicolumn{3}{c}{ Selectivity ${ }^{\mathbf{c}}$} \\
\cline { 5 - 6 } & & & HFCA & FDCA & Others \\
\hline 0 & 89 & 80 & $68^{\mathrm{d}}$ & $2 \mathrm{~d}$ & $30^{\mathrm{d}}$ \\
1 & 301 & 98 & 15 & 84 & 1 \\
2 & 368 & $>99$ & 2 & 96 & 2 \\
4 & 403 & - & 92 & 5 \\
\hline
\end{tabular}

a Reaction conditions: HMF $0.15 \mathrm{M}$, alcohol/metal molar ratio: $200, \mathrm{~T}=60^{\circ} \mathrm{C}, \mathrm{pO}_{2}=3$ atm; ${ }^{\mathrm{b}}$ mol of $\mathrm{HMF}$ converted per hour per mol of metal, calculated after 15 min reaction; ${ }^{c}$ selectivity at $90 \%$ of conversion; ${ }^{d}$ selectivity at $10 \%$ of conversion.

Increasing the temperature from 30 to $80{ }^{\circ} \mathrm{C}$ has a positive effect on the activity and in the transformation of HFCA to FDCA (Table 6). However, it can be observed that at higher temperature, for example, at $80^{\circ} \mathrm{C}$, the amount of undesired products increases $(11 \%)$, whereas at lower temperature, the concentration of by-products is $<2 \%$.

Table 6. Effect of temperature using $\mathrm{Au}-\mathrm{Pt} / \mathrm{P}-\mathrm{HHT}-\mathrm{CNF}{ }^{\mathrm{a}}$.

\begin{tabular}{cccccc}
\hline \multirow{2}{*}{ Temperature $\left({ }^{\circ} \mathbf{C}\right)$} & $\begin{array}{c}\text { Activity } \\
\mathbf{( h}^{-\mathbf{1}} \mathbf{)}\end{array}$ & $\begin{array}{c}\text { Conversion } \\
\text { After } \mathbf{1} \mathbf{~ h}\end{array}$ & & \multicolumn{3}{c}{ Selectivity $^{\mathbf{c}}$} \\
\cline { 5 - 6 } & 243 & 84 & 22 & 78 & - \\
\hline 30 & 321 & 97 & 6 & 93 & 1 \\
60 & 368 & 98 & 2 & 96 & 2 \\
80 & 393 & $>99$ & - & 89 & 11 \\
\hline
\end{tabular}

${ }^{a}$ Reaction conditions: HMF $0.15 \mathrm{M}$, alcohol/metal molar ratio: $200, \mathrm{pO}_{2}=3 \mathrm{~atm}, 2$ eq. $\mathrm{NaOH}^{\mathrm{b}}{ }^{\mathrm{m}} \mathrm{mol}$ of $\mathrm{HMF}$ converted per hour per mol of metal, calculated after $15 \mathrm{~min}$ reaction; ${ }^{\mathrm{c}}$ selectivity at $90 \%$ of conversion.

Varying the oxygen pressure from 1 to 5 bar, it can be observed that the HMF conversion maintains almost complete after $1 \mathrm{~h}$ in the range of examined pressures (Table 7). However, large differences were observed in the FDCA production. Indeed, $\mathrm{O}_{2}$ pressures higher than $3 \mathrm{~atm}$ were necessary to achieve high selectivity ( $>96 \%$ at $80 \%$ conversion) to FDCA.

Table 7. Effect of $\mathrm{O}_{2}$ pressure using Au-Pt/P-HHT-CNF ${ }^{\mathrm{a}}$.

\begin{tabular}{cccccc}
\hline \multirow{2}{*}{$\begin{array}{c}\text { Oxygen Pressure } \\
\text { Atm }\end{array}$} & \multirow{2}{*}{$\begin{array}{c}\text { Activity } \\
\mathbf{( h}^{-\mathbf{1}} \mathbf{)}\end{array}$} & \multirow{2}{*}{$\begin{array}{c}\text { Conversion } \\
\text { After } \mathbf{1} \mathbf{h}\end{array}$} & & \multicolumn{3}{c}{ Selectivity $^{\mathbf{c}}$} \\
\cline { 4 - 6 } & & & HFCA & FDCA & Others \\
\hline 1 & 325 & 95 & 53 & 33 & 14 \\
3 & 358 & 98 & 21 & 76 & 3 \\
5 & 368 & $>99$ & 2 & 96 & 2 \\
\hline
\end{tabular}

${ }^{a}$ Reaction conditions: HMF $0.15 \mathrm{M}$, alcohol/metal: $200, \mathrm{~T}=60^{\circ} \mathrm{C} 2$ eq. $\mathrm{NaOH} ;{ }^{\mathrm{b}} \mathrm{mol}$ of HMF converted per hour per mol of metal, calculated after 15 min reaction; ${ }^{c}$ selectivity at $80 \%$ of conversion.

Combining the results attained and varying the reaction parameters, it is possible to identify the optimal operative conditions for the selective oxidation of HMF to FDCA in the presence $\mathrm{Au}-\mathrm{Pt} / \mathrm{P}-\mathrm{HHT}-\mathrm{CNF}$; working at $60^{\circ} \mathrm{C}$, with 2 equiv. $\mathrm{NaOH}$ and 5 bar of pressure, allows to reach the maximum yield to FDCA. Therefore, in order to study the durability of the catalyst, stability tests have been performed under the optimized reaction conditions. Recycling tests have been performed by filtering the catalyst after each run and reusing it without any pretreatment. The results have been reported as yield to FDCA. 
Figure 4 showed that the catalyst is stable after six runs. Atomic absorption spectroscopy (AAS) performed on the solution did not reveal any leaching of metal components ( $\mathrm{Au}-\mathrm{Pt}$ ) or phosphorus during the reaction.

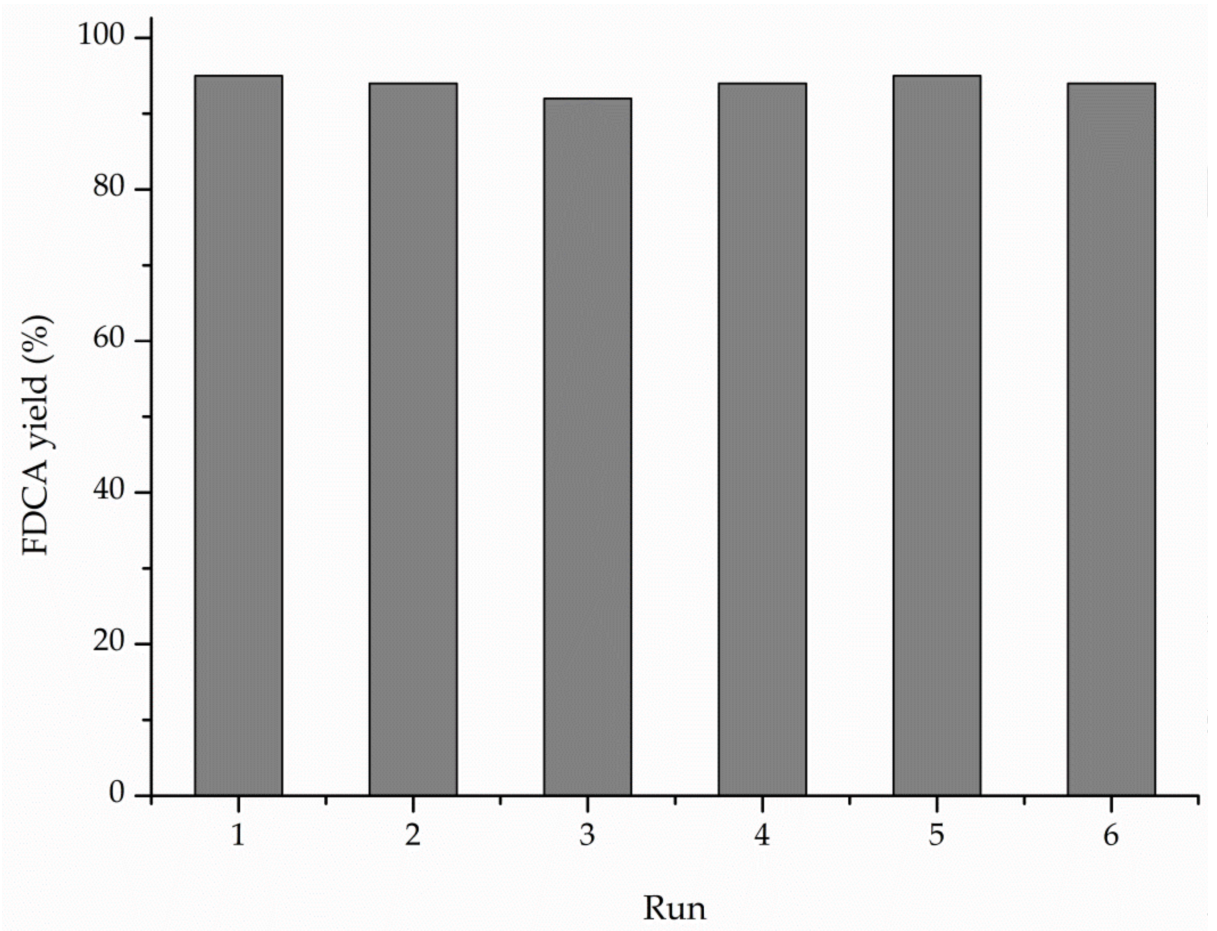

Figure 4. Stability tests using Au-Pt/P-HHT-CNF. Reaction conditions: HMF 0.15 M, alcohol/metal molar ratio: $200, \mathrm{pO}_{2}=5 \mathrm{~atm}, \mathrm{~T}=60{ }^{\circ} \mathrm{C} 2$ eq. $\mathrm{NaOH}$.

\section{Discussion}

Three commercial carbon nanofibers (CNFs) with different graphitization degree, PS-CNFs, LHT-CNFs, and HHT-CNFs, have been selected as pristine carbon materials to be doped with $\mathrm{P}$-containing functionalities and then used as support for bimetallic $\mathrm{Au}-\mathrm{Pt} \mathrm{NPs}$. The incorporation of phosphorus on these materials has been previously reported to proceed successfully [45]. Moreover, as-obtained P-doped CNFs have demonstrated to be effective metal-free catalysts for the selective fructose dehydration to 5-hydroxymethyl furfural (HMF) [44]. On the basis of these promising results, we explored the potentiality of $\mathrm{P}-\mathrm{CNFs}$ as supports for $\mathrm{Au}-\mathrm{Pt}$-based catalysts in the selective oxidation of HMF to furan dicarboxylic acid (FDCA). The functionalization was performed by treating pristine $\mathrm{CNFs}$ with a $\mathrm{HNO}_{3}-\mathrm{H}_{3} \mathrm{PO}_{4} 1: 1 \mathrm{vol} / \mathrm{vol}$ mixture at $250{ }^{\circ} \mathrm{C}$. Beside introducing $\mathrm{O}$ - and P-functionalities, this treatment altered the defectiveness of the materials as evidenced by evaluating the $I_{D} / I_{G}$ ratio from Raman spectra. In particular, an enhancement of graphitization was obtained for PS-CNFs, while an opposite trend was revealed for LHT-CNFs. No significant variations were observed for HHT-CNFs, which still result in the more graphitic materials.

The immobilization of Au-Pt NPs on P-CNFs produced catalysts with similar mean metal particle sizes (3-4 nm) as evidenced by TEM analysis. Although surface doping is usually known to provide effective anchoring sites able to stabilize very small metal NPs, in this case, the introduction of P-functionalities did not improve the metal dispersion compared with undoped CNFs. The presence of large aggregates was disclosed by STEM-EDX analysis in all the samples, independent of the nature of the support. Au-Pt-based materials were tested as catalysts in HMF oxidation reaction and the catalytic performances were compared with the ones of monometallic Au or Pt counterparts. As expected, the addition of $\mathrm{Au}$ to Pt resulted in more active catalysts compared with monometallic systems, as a consequence of the insurgence of synergistic effects. Working with same particle size of 
metal nanoparticles allowed us to rule out metal particle size effect, and thus to unveil the role of the support in determining the catalytic behavior of studied materials (Table 8).

Table 8. Relation between catalyst structural properties and catalytic results.

\begin{tabular}{|c|c|c|c|c|c|c|c|}
\hline \multirow{2}{*}{ Catalyst } & \multicolumn{5}{|c|}{ Catalyst Structural Properties } & \multicolumn{2}{|c|}{ Catalytic Results } \\
\hline & $\begin{array}{l}\text { P Content in } \\
\text { Bare Support } \\
\quad(\% \text { at. })^{a}\end{array}$ & $\begin{array}{l}\text { Graphitization } \\
\text { Degree }\left(I_{D} / I_{G}\right)^{\mathrm{b}}\end{array}$ & $\begin{array}{l}\text { Particle Size } \\
\quad(\mathrm{nm})^{\mathrm{c}}\end{array}$ & $\begin{array}{l}\mathrm{Pt}^{0} / \mathrm{Pt}^{2+} \\
\text { Ratio }^{\mathrm{a}}\end{array}$ & $\begin{array}{l}\text { Au } 4 f_{7 / 2} \text { Peak } \\
\text { Position }(e V)^{a}\end{array}$ & $\begin{array}{l}\text { Activity } \\
\left(\mathrm{h}^{-1}\right)^{\mathrm{d}}\end{array}$ & $\begin{array}{l}\text { FDCA/HFCA } \\
\text { Molar Ratio }^{\text {e }}\end{array}$ \\
\hline $\mathrm{Au}-\mathrm{Pt} / \mathrm{P}-\mathrm{PS}-\mathrm{CNF}$ & 0.23 & 0.63 & $5.2 \pm 0.3$ & 4.7 & 84.07 & 144 & 1.4 \\
\hline $\mathrm{Au}-\mathrm{Pt} / \mathrm{P}-\mathrm{LHT}-\mathrm{CNF}$ & 0.24 & 0.53 & $4.3 \pm 0.3$ & 6.4 & 84.06 & 171 & 1.7 \\
\hline $\mathrm{Au}-\mathrm{Pt} / \mathrm{P}-\mathrm{HHT}-\mathrm{CNF}$ & 1.19 & 0.50 & $3.9 \pm 0.3$ & 7.6 & 84.12 & 368 & 48 \\
\hline
\end{tabular}

${ }^{a}$ Determined by XPS analysis; ${ }^{b}$ calculated from Raman spectra by peak fitting analysis was performed based on Gaussian functions; ${ }^{c}$ from TEM analysis; ${ }^{\mathrm{d}}$ mol of HMF converted per hour per mol of metal, calculated after 15 min reaction; ${ }^{\mathrm{e}}$ evaluated at $90 \%$ of conversion.

As general trend, the incorporation of $\mathrm{P}$ on the support slightly improved the activity of $\mathrm{Au}-\mathrm{Pt}$-based catalysts. From the evaluation of activity, conversion, and selectivity at iso-conversion, $\mathrm{Au}-\mathrm{Pt} / \mathrm{P}-\mathrm{HHT}-\mathrm{CNF}$ emerged as the best catalyst (activity $368 \mathrm{~h}^{-1}, 98 \%$ conversion after $2 \mathrm{~h}$, and $96 \%$ selectivity to FDCA at $80 \%$ conversion). Analyzing the product distribution as a function of the reaction time for the studied catalysts, it appears clear that $\mathrm{Au}-\mathrm{Pt} / \mathrm{P}-\mathrm{HHT}-\mathrm{CNF}$ is the only catalyst able to quantitatively oxidize HFCA to FDCA (Figure 3 and Table 8). This evidence could be related to the interaction between $\mathrm{Au}-\mathrm{Pt}$ NPs and P functionalities of the support. Chen et al. [28] reported that $\mathrm{Pd}^{2+}$ species are stabilized by $\mathrm{P}$ functionalities in Pd NPs deposited on highly porous phosphorus-doped graphene sheet. The $\mathrm{Pd}^{2+}$ species are involved in accelerating the oxidation of hydroxyl group of HFCA into aldehyde group of 5-formyl-2-furancarboxylic acid (FFCA), which is the rate-determining step in FDCA production from HMF. A linear dependence of the activation energy for FDCA production on the fraction of $\mathrm{Pd}^{2+}$ has been observed. In our case, XPS analysis revealed a shift to higher binding energy for $\mathrm{Au} 4 \mathrm{f}_{7 / 2}$ signal of Au-Pt NPs supported on P-doped CNFs (Tables 4 and 8). This shift could be ascribed to a decreased electron density on gold centers and it is more pronounced for the $\mathrm{Au}-\mathrm{Pt} / \mathrm{P}-\mathrm{HHT}-\mathrm{CNF}$ catalysts, which contains the highest P-content and showed the best catalytic performances in HMF oxidation to FDCA. Consequently, we might guess an effect similar to the one disclosed by Chen et al. for Pd catalysts; the P functionalities of the support are able to stabilize $\mathrm{Au}^{\delta+}$ species, which might be responsible for the high FDCA production. This evidence has not been reported previously for Au-based catalysts in HMF oxidation, but it is in agreement with the results of Wang et al. [25], who studied phosphorus-doped carbon as supports for gold-based catalysts in acetylene hydrochlorination. The authors ascribed the enhanced catalytic performances of the studied catalysts to the stabilization of the catalytic active gold species $\mathrm{Au}^{3+}$ through specific interaction with phosphate groups on support surface.

The presence of $\mathrm{P}$ on carbon surface also influences the oxidation state of $\mathrm{Pt}$ and in particular, the higher the content of $\mathrm{P}$ in the support, the higher the $\mathrm{Pt}^{0} / \mathrm{Pt}^{2+}$ ratio. This experimental outcome might reveal an opposite trend for Pt compared with Pd and Au. Indeed, it seems that a higher P content is associated with a greater stabilization of $\mathrm{Pt}^{0}$ than $\mathrm{Pt}^{2+}$ species. This apparent contradiction might find a possible explanation in the particular synthetic route used for the preparation of $\mathrm{Au}-\mathrm{Pt}$ catalysts. Indeed, in our two-step procedure, Pt addition occurred in the second step, when Au NPs have been already immobilized on the support. Therefore, it may reasonably be supposed that when $\mathrm{Pt}$ is introduced on the catalyst surface, no phosphate groups are available to interact with $\mathrm{Pt}^{2+}$ ions, as they are involved in strong interactions with Au centers. Consequently, $\mathrm{Pt}^{2+}$ ions undergo reduction in the presence of $\mathrm{H}_{2}$, thus forming metal Pt NPs. However, in this hypothesis $\mathrm{Pt}^{0} / \mathrm{Pt}^{2+}$ ratio should be insensitive to the P-content, in contrast to experimental evidences. Again, the interactions between $\mathrm{Au}$ and phosphate groups could be invoked to justify the $\mathrm{Pt}^{0} / \mathrm{Pt}^{2+}$ ratio dependence on P-content. Indeed, it is known that because of the difference in Fermi levels, electrons tend to migrate from $\mathrm{Pt}$ to $\mathrm{Au}$, when the two metals are contacted. In our case, the strong interaction between phosphate groups 
and $\mathrm{Au}$ NPs would make $\mathrm{Au}^{\delta+}$ centers less prone to be reduced by $\mathrm{Pt}$, thus minimizing the electron flow from $\mathrm{Pt}$ to $\mathrm{Au}$ and the consequent formation of $\mathrm{Pt}^{2+}$ species (Scheme 2).

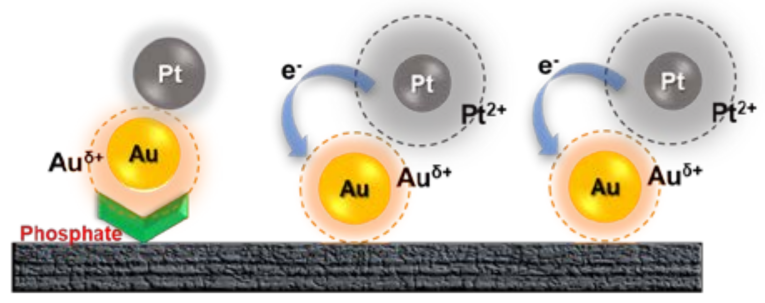

Low P-content

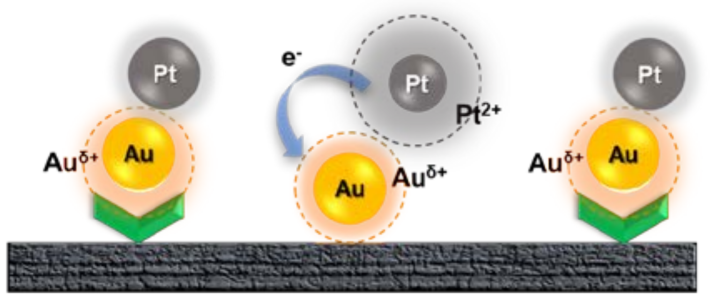

High P-content

Scheme 2. Possible effect of $\mathrm{P}$-content on $\mathrm{Pt}^{0} / \mathrm{Pt}^{2+}$ ratio.

Considering that $\mathrm{Pt}^{0}$ has been reported to play a key role in $\mathrm{HMF}$ oxidation [51,52], we cannot rule out a concomitant influence of the $\mathrm{Pt}^{0} / \mathrm{Pt}^{2+}$ ratio on the catalytic performances. In fact, the best catalytic performances have been attained with $\mathrm{Au}-\mathrm{Pt} / \mathrm{P}-\mathrm{HHT}-\mathrm{CNF}$, which also possesses the highest $\mathrm{Pt}^{0} / \mathrm{Pt}^{2+}$ ratio.

Finally, the experimental conditions have been optimized in order to maximize the FDCA yield. It has been found that at $60^{\circ} \mathrm{C}$, with 2 equiv. $\mathrm{NaOH}$ and 5 bar of pressure, it is possible to quantitatively and selectively oxidize HMF to FDCA. Under these conditions, the catalyst was stable up to six runs (Figure 4).

\section{Conclusions}

In summary, we have reported the potential of Au-Pt nanoparticle deposited on phosphorus functionalized carbon nanofibers as effective catalysts for the oxidation of 5-hydroxymethylfurfural (HMF) to furandicarboxylic acid (FDCA).

The graphitization degree of pristine CNFs plays a crucial role in controlling the incorporation of phosphate groups. The higher the graphitization degree, the higher the content of phosphorus (1.19\% for HHT CNFs).

$\mathrm{Au}-\mathrm{Pt} / \mathrm{P}-\mathrm{CNF}$ demonstrated to be highly active, selective, and stable catalysts under selected operative conditions.

The activity and mostly the selectivity to FDCA seem to be affected by the amount of $P$ incorporated in the CNF surface. Remarkable results have been obtained with the catalysts with the highest P-content, Au-Pt/P-HHT-CNF, which selectively converted HMF to FDCA after $1 \mathrm{~h}$ (98\% selectivity to FDCA at $80 \%$ conversion) and showed excellent stability up to six runs. This evidence suggests a possible role of $\mathrm{Au}-\mathrm{P}$ interactions affecting the electronic properties of active sites. Further investigations are necessary to understand the detailed reaction mechanism, the involved species, and the role of P-functionalities.

Supplementary Materials: The following are available online at http:/ / www.mdpi.com/2311-5629/4/3/48/s1, Figure S1: Effect of Metal/substrate ratio using Au-Pt/P-HHT-CNF, Figure S2: Effect of stirring rate using $\mathrm{Au}-\mathrm{Pt} / \mathrm{P}-\mathrm{HHT}-\mathrm{CNF}$, Table S1: Particle size for CNFs based catalysts.

Author Contributions: Conceptualization, S.C. (Sebastiano Campisi), L.P., N.D., and A.V.; Data curation, S.C. (Sebastiano Campisi), S.C. (Sofia Capelli), D.M., F.JS.T., T.E.D., and A.V.; Investigation, S.C. (Sebastiano Campisi), S.C. (Sofia Capelli), D.M., F.JS.T., T.E.D., and A.V.; Project administration, S.C. (Sebastiano Campisi) and A.V.; Supervision, S.C. (Sebastiano Campisi), L.P., N.D., and A.V.; Validation, S.C. (Sebastiano Campisi), N.D., and A.V.; Writing original draft, S.C. (Sebastiano Campisi), L.P., N.D., and A.V.; S.C. (Sebastiano Campisi) and A.V. designed the experiments and carried out catalytic evaluation; S.C. (Sofia Capelli) and F.JS.T. carried out and helped in the evaluation of the Raman; S.C. (Sofia Capelli) and T.E.D. performed TEM experiments and helped in the interpretation; D.M. carried out the XPS experiments and helped in the interpretation; S.C. (Sebastiano Campisi), A.V., N.D., and L.P. were involved in the writing and editing the manuscript.

Funding: This research received no external funding. 
Acknowledgments: Sofia Capelli thanks the Erasmus Programme Agreement between Milan and Cardiff Universities.

Conflicts of Interest: The authors declare no conflict of interest.

\section{References}

1. Rodríguez-Reinoso, F. The role of carbon materials in heterogeneous catalysis. Carbon 1998, 36, $159-175$. [CrossRef]

2. Serp, P.; Figueiredo, J.L. Carbon Materials for Catalysis; John Wiley \& Sons: New Jersey, NJ, USA, 2009; ISBN 9780470178850.

3. Bitter, J.H. Nanostructured carbons in catalysis a Janus material industrial applicability and fundamental insights. J. Mater. Chem. 2010, 20, 7312-7321. [CrossRef]

4. Su, D.S.; Perathoner, S.; Centi, G. Nanocarbons for the development of advanced catalysts. Chem. Rev. 2013, 113, 5782-5816. [CrossRef] [PubMed]

5. Lam, E.; Luong, J.H.T. Carbon materials as catalyst supports and catalysts in the transformation of biomass to fuels and chemicals. ACS Catal. 2014, 4, 3393-3410. [CrossRef]

6. Prati, L.; Villa, A.; Lupini, A.R.; Veith, G.M. Gold on carbon: One billion catalysts under a single label. Phys. Chem. Chem. Phys. 2012, 14, 2969-2978. [CrossRef] [PubMed]

7. Pérez-Rodriguez, S.; Rillo, N.; Lazaro, M.J.; Pastor, E. Pd catalysts supported onto nanostructured carbon materials for $\mathrm{CO}_{2}$ valorization by electrochemical reduction. Appl. Catal. B Environ. 2015, 163, 83-95. [CrossRef]

8. Tasis, D.; Tagmatarchis, N.; Bianco, A.; Prato, M. Chemistry of carbon nanotubes. Chem. Rev. 2006, 106, 1105-1136. [CrossRef] [PubMed]

9. Villa, A.; Dimitratos, N. (Eds.) Catalysis Series. In Metal-Free Functionalized Carbons in Catalysis; Royal Society of Chemistry: Cambridge, UK, 2018; ISBN 978-1-78262-863-7.

10. Balasubramanian, K.; Burghard, M. Chemically functionalized carbon nanotubes. Small 2005, 1, $180-192$. [CrossRef] [PubMed]

11. Lee, W.J.; Maiti, U.N.; Lee, J.M.; Lim, J.; Han, T.H.; Kim, S.O. Nitrogen-doped carbon nanotubes and graphene composite structures for energy and catalytic applications. Chem. Commun. 2014, 50, 6818-6830. [CrossRef] [PubMed]

12. Fraga, M.A.; Jordão, E.; Mendes, M.J.; Freitas, M.M.A.; Faria, J.L.; Figueiredo, J.L. Properties of carbon-supported platinum catalysts: Role of carbon surface sites. J. Catal. 2002, 209, 355-364. [CrossRef]

13. Campisi, S.; Chan-Thaw, C.; Villa, A. Understanding heteroatom-mediated metal-support interactions in functionalized carbons: A. perspective review. Appl. Sci. 2018, 8, 1159. [CrossRef]

14. Rocha, R.; Soares, O.; Figueiredo, J.; Pereira, M. Tuning CNT properties for metal-free environmental catalytic applications. C 2016, 2, 17. [CrossRef]

15. Ovejero, G.; Sotelo, J.L.; Romero, M.D.; Rodríguez, A.; Ocaña, M.A.; Rodríguez, G.; García, J. Multiwalled carbon nanotubes for liquid-phase oxidation functionalization, characterization, and catalytic activity. Ind. Eng. Chem. Res. 2006, 45, 2206-2212. [CrossRef]

16. Figueiredo, J.L.; Pereira, M.F.R. The role of surface chemistry in catalysis with carbons. Catal. Today 2010, 150, 2-7. [CrossRef]

17. Figueiredo, J.L.; Pereira, M.F.R.; Freitas, M.M.A.; Órfão, J.J.M. Modification of the surface chemistry of activated carbons. Carbon 1999, 37, 1379-1389. [CrossRef]

18. Li, J.; Tian, Q.; Jiang, S.; Zhang, Y.; Wu, Y. Electrocatalytic performances of phosphorus doped carbon supported Pd towards formic acid oxidation. Electrochim. Acta 2016, 213, 21-30. [CrossRef]

19. Silva, J.C.M.; de Freitas, I.C.; Neto, A.O.; Spinacé, E.V.; Ribeiro, V.A. Palladium nanoparticles supported on phosphorus-doped carbon for ethanol electro-oxidation in alkaline media. Ionics 2018, 24, 1111-1119. [CrossRef]

20. Higgins, D.C.; Meza, D.; Chen, Z. Nitrogen-doped carbon nanotubes as platinum catalyst supports for oxygen reduction reaction in proton exchange membrane fuel cells. J. Phys. Chem. C 2010, 114, 21982-21988. [CrossRef]

21. Liu, Z.; Shi, Q.; Zhang, R.; Wang, Q.; Kang, G.; Peng, F. Phosphorus-doped carbon nanotubes supported low Pt loading catalyst for the oxygen reduction reaction in acidic fuel cells. J. Power Sources 2014, 268, 171-175. [CrossRef] 
22. Shiva, K.S.; Ramakrishna, S.U.B.; Rama, D.B.; Himabindu, V. Phosphorus-doped carbon nanoparticles supported palladium electrocatalyst for the hydrogen evolution reaction (HER) in PEM water electrolysis. Ionics 2018, 1-9. [CrossRef]

23. Yin, M.; Huang, Y.; Li, Q.; Jensen, J.O.; Cleemann, L.N.; Zhang, W.; Bjerrum, N.J.; Xing, W. Phosphate-Doped carbon black as $\mathrm{Pt}$ catalyst support: Co-catalytic functionality for dimethyl ether and methanol electro-oxidation. ChemElectroChem 2014, 1, 448-454. [CrossRef]

24. Zhu, J.; He, G.; Liang, L.; Wan, Q.; Shen, P.K. Direct anchoring of platinum nanoparticles on nitrogen and phosphorus-dual-doped carbon nanotube arrays for oxygen reduction reaction. Electrochim. Acta 2015, 158, 374-382. [CrossRef]

25. Wang, B.; Yu, L.; Zhang, J.; Pu, Y.; Zhang, H.; Li, W. Phosphorus-doped carbon supports enhance gold-based catalysts for acetylene hydrochlorination. RSC Adv. 2014, 4, 15877-15885. [CrossRef]

26. Lu, C.; Wang, M.; Feng, Z.; Qi, Y.; Feng, F.; Ma, L.; Zhang, Q.; Li, X. A phosphorus-carbon framework over activated carbon supported palladium nanoparticles for the chemoselective hydrogenation of para-chloronitrobenzene. Catal. Sci. Technol. 2017, 7, 1581-1589. [CrossRef]

27. Guo, W.; Niu, S.; Shi, W.; Zhang, B.; Yu, W.; Xie, Y.; Ji, X.; Wu, Y.; Su, D.; Shao, L. Pd-P nanoalloys supported on a porous carbon frame as an efficient catalyst for benzyl alcohol oxidation. Catal. Sci. Technol. 2018, 8, 2333-2339. [CrossRef]

28. Chen, C.; Li, X.; Wang, L.; Liang, T.; Wang, L.; Zhang, Y.; Zhang, J. Highly porous nitrogen- and phosphorus-codoped graphene: An outstanding support for Pd catalysts to oxidize 5-hydroxymethylfurfural into 2,5-furandicarboxylic acid. ACS Sustain. Chem. Eng. 2017, 5, 11300-11306. [CrossRef]

29. Gandini, A.; Silvestre, A.J.D.; Neto, C.P.; Sousa, A.F.; Gomes, M. The furan counterpart of polyethylene terephthalate: An alternative material based on renewable resources. J. Polym. Sci. Part A Polym. Chem. 2009, 47, 295-298. [CrossRef]

30. Nakajima, H.; Dijkstra, P.; Loos, K. The recent developments in biobased polymers toward general and engineering applications: Polymers that are upgraded from biodegradable polymers, analogous to petroleum-derived polymers, and newly developed. Polymers 2017, 9, 523. [CrossRef]

31. Rosatella, A.A.; Simeonov, S.P.; Frade, R.F.M.; Afonso, C.A.M. 5-Hydroxymethylfurfural (HMF) as a building block platform: Biological properties, synthesis and synthetic applications. Green Chem. 2011, 13, 754-793. [CrossRef]

32. Corma Canos, A.; Iborra, S.; Velty, A. Chemical routes for the transformation of biomass into chemicals. Chem. Rev. 2007, 107, 2411-2502. [CrossRef] [PubMed]

33. Besson, M.; Gallezot, P.; Pinel, C. Conversion of biomass into chemicals over metal catalysts. Chem. Rev. 2014, 114, 1827-1870. [CrossRef] [PubMed]

34. Casanova, O.; Iborra, S.; Corma, A. Biomass into chemicals: Aerobic oxidation of 5-hydroxymethyl-2-furfural into 2,5-furandicarboxylic acid with gold nanoparticle catalysts. ChemSusChem Chem. Sustain. Energy Mater. 2009, 2, 1138-1144. [CrossRef] [PubMed]

35. Davis, S.E.; Houk, L.R.; Tamargo, E.C.; Datye, A.K.; Davis, R.J. Oxidation of 5-hydroxymethylfurfural over supported Pt, Pd and Au catalysts. Catal. Today 2011, 160, 55-60. [CrossRef]

36. Zheng, L.; Zhao, J.; Du, Z.; Zong, B.; Liu, H. Efficient aerobic oxidation of 5-hydroxymethylfurfural to 2,5-furandicarboxylic acid on Ru/C. catalysts. Sci. China Chem. 2017, 60, 950-957. [CrossRef]

37. Pasini, T.; Piccinini, M.; Blosi, M.; Bonelli, R.; Albonetti, S.; Dimitratos, N.; Lopez-Sanchez, J.A.; Sankar, M.; He, Q.; Kiely, C.J.; et al. Selective oxidation of 5-hydroxymethyl-2-furfural using supported gold-copper nanoparticles. Green Chem. 2011, 13, 2091-2099. [CrossRef]

38. Artz, J.; Palkovits, R. Base-Free aqueous-phase oxidation of 5-hydroxymethylfurfural over ruthenium catalysts supported on covalent triazine frameworks. ChemSusChem. 2015, 8, 3832-3838. [CrossRef] [PubMed]

39. Yi, G.; Teong, S.P.; Zhang, Y. Base-free conversion of 5-hydroxymethylfurfural to 2,5-furandicarboxylic acid over a Ru/C catalyst. Green Chem. 2016, 18, 979-983. [CrossRef]

40. Davis, S.E.; Zope, B.N.; Davis, R.J. On the mechanism of selective oxidation of 5-hydroxymethylfurfural to 2,5-furandicarboxylic acid over supported Pt and Au catalysts. Green Chem. 2012, 14, 143-147. [CrossRef]

41. Zope, B.N.; Davis, S.E.; Davis, R.J. Influence of reaction conditions on diacid formation during Au-catalyzed oxidation of glycerol and hydroxymethylfurfural. Top. Catal. 2012, 55, 24-32. [CrossRef] 
42. Zhou, C.; Deng, W.; Wan, X.; Zhang, Q.; Yang, Y.; Wang, Y. Functionalized carbon nanotubes for biomass conversion: The base-free aerobic oxidation of 5-hydroxymethylfurfural to 2,5-furandicarboxylic acid over platinum supported on a carbon nanotube catalyst. Chem CatChem 2015, 7, 2853-2863. [CrossRef]

43. Wan, X.; Zhou, C.; Chen, J.; Deng, W.; Zhang, Q.; Yang, Y.; Wang, Y. Base-free aerobic oxidation of 5-hydroxymethyl-furfural to 2,5-furandicarboxylic acid in water catalyzed by functionalized carbon nanotube-supported Au-Pd alloy nanoparticles. ACS Catal. 2014, 4, 2175-2185. [CrossRef]

44. Villa, A.; Schiavoni, M.; Campisi, S.; Veith, G.M.; Prati, L. Pd-modified Au on carbon as an effective and durable catalyst for the direct oxidation of HMF to 2,5-furandicarboxylic acid. ChemSusChem 2013, 6, 609-612. [CrossRef] [PubMed]

45. Campisi, S.; Sanchez Trujillo, F.; Motta, D.; Davies, T.; Dimitratos, N.; Villa, A. Controlling the incorporation of phosphorus functionalities on carbon nanofibers: Effects on the catalytic performance of fructose dehydration. C 2018, 4, 9. [CrossRef]

46. Tessonnier, J.P.; Rosenthal, D.; Hansen, T.W.; Hess, C.; Schuster, M.E.; Blume, R.; Girgsdies, F.; Pfaender, N.; Timpe, O.; Su, D.S.; et al. Analysis of the structure and chemical properties of some commercial carbon nanostructures. Carbon 2009, 47, 1779-1798. [CrossRef]

47. Torres, D.; Pinilla, J.L.; Moliner, R.; Suelves, I. On the oxidation degree of few-layer graphene oxide sheets obtained from chemically oxidized multiwall carbon nanotubes. Carbon 2015, 81, 405-417. [CrossRef]

48. Villa, A.; Manzoli, M.; Vindigni, F.; Chinchilla, L.E.; Botton, G.A.; Prati, L. Diols production from glycerol over Pt-Based catalysts: On the role played by the acid sites of the support. Catal. Lett. 2017, 147, 2523-2533. [CrossRef]

49. Jouve, A.; Stucchi, M.; Barlocco, I.; Evangelisti, C.; Somodic, F.; Villa, A.; Prati, L. Carbon-Supported au nanoparticles: Catalytic activity ruled out by carbon support. Top. Catal. 2018, 1-11. [CrossRef]

50. Gil, S.; Muñoz, L.; Sánchez-Silva, L.; Romero, A.; Valverde, J.L. Synthesis and characterization of Au supported on carbonaceous material-based catalysts for the selective oxidation of glycerol. Chem. Eng. J. 2011, 172, 418-429. [CrossRef]

51. Han, X.; Geng, L.; Guo, Y.; Jia, R.; Liu, X.; Zhang, Y.; Wang, Y. Base-free aerobic oxidation of 5-hydroxymethylfurfural to 2,5-furandicarboxylic acid over a Pt/C-O-Mg catalyst. Green Chem. 2016, 18, 1597-1604. [CrossRef]

52. Ait, R.H.; Essayem, N.; Besson, M. Selective aqueous phase oxidation of 5-hydroxymethylfurfural to 2,5-furandicarboxylic acid over $\mathrm{Pt} / \mathrm{C}$ catalysts: Influence of the base and effect of bismuth promotion. Green Chem. 2013, 15, 2240-2251.

(C) 2018 by the authors. Licensee MDPI, Basel, Switzerland. This article is an open access article distributed under the terms and conditions of the Creative Commons Attribution (CC BY) license (http://creativecommons.org/licenses/by/4.0/). 